\title{
In Memoriam: Sidney George Shaw, DPhil (1948-2017)
}

\author{
M. BARTON ${ }^{1}$, H. J. LITTLE ${ }^{2}$, R. D. VAUGHAN-JONES ${ }^{2}$, S. DANIELS ${ }^{2}$, \\ M. R. DASHWOOD ${ }^{3}$, J. C. TSUI ${ }^{3}$ \\ ${ }^{1}$ University of Zürich, Switzerland, ${ }^{2}$ Oxford University, United Kingdom, ${ }^{3}$ University College \\ London, United Kingdom
}

Received February 7, 2018

Accepted February 12, 2018

«We are here to add what we can, to, not to get what we can get from, life.»

Sir William Osler, Regius Professor of Medicine at Oxford University

(Osler 1891)

\begin{abstract}
Summary
On March 4, 2017 at the age of 68, Sidney George Shaw (Sid) unexpectedly died from complications following surgery, only four years after retiring from the University of Bern. Trained in biochemistry at Oxford University, Sid had quickly moved into molecular pharmacology and became a key investigator in the field of enzyme biochemistry, vasoactive peptide research, and receptor signaling. Sid spent half his life in Switzerland, after moving to the University of Bern in 1984 . This article, written by his friends and colleagues who knew him and worked with him during different stages of his career, summarizes his life, his passions, and his achievements in biomedical research. It also includes personal memories relating to a dear friend and outstanding scientist whose intellectual curiosity, humility, and honesty will remain an example to us all.
\end{abstract}

\section{Corresponding authors}

M. Barton, Molecular Internal Medicine, Y44 G22, University of Zürich, Winterthurerstrasse 190, CH-8057 Zürich, Switzerland. E-mail: barton@access.uzh.ch

and

J. C. Tsui, Division of Surgery and Interventional Science, University College London, Royal Free Campus, London NW3 2QG, United Kingdom. E-mail: janice.tsui@ucl.ac.uk
The above quote by Canadian physician Sir William Osler (1849-1919) undoubtedly gives a good summary of the working ethos that Sidney "Sid" George Shaw (Fig. 1) followed his entire life. On March 4, 2017 at the age of 68 , Sid unexpectedly died from complications following surgery a few weeks earlier, and only four years after retiring from the University of Bern. Born in Liverpool and trained in biochemistry at Oxford University, Sid quickly moved into molecular pharmacology. He spent half his life in Switzerland, after moving to the University of Bern in 1984. There, he became a key investigator in the fields of enzyme biochemistry, vasoactive peptide research, and GPCR signaling and function. In this article, his friends and colleagues who knew him and worked with him during different stages of his career, summarize his life, his passions, and achievements in biomedical research. The article also includes personal memories relating to a dear friend and outstanding scientist whose intellectual curiosity, humility, and honesty will remain an example to us all. 

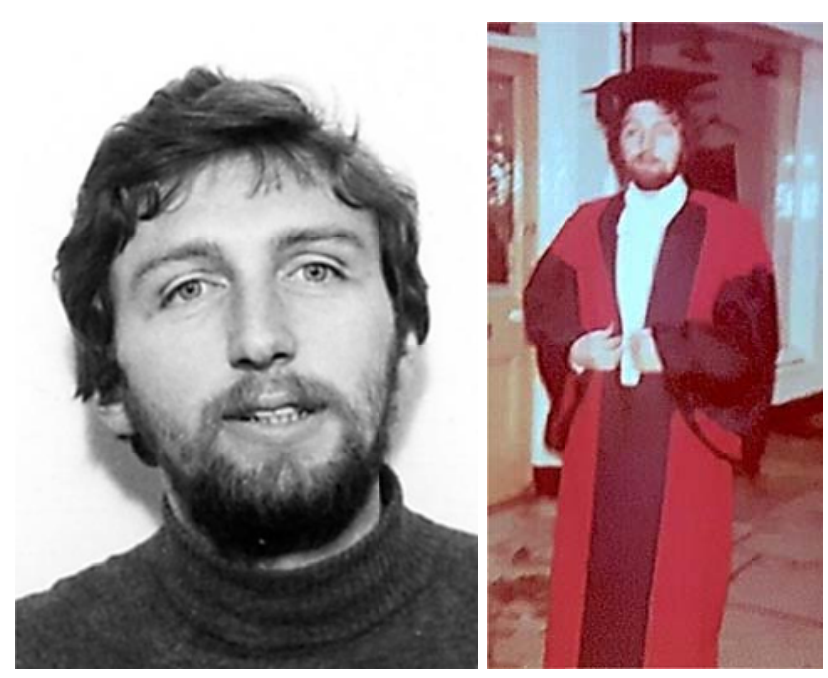

Fig. 1. Left: Picture of young Sid Shaw at the age of 28, taken in 1976 in Oxford. Right: Sid in his DPhil gown of Oxford University after the thesis ceremony 1978 . The picture was taken at the celebration of Sid's degree which he shared with Stephen Daniels and was at the Royal Oak pub in Oxford; after they had drunk all the champagne they rushed off in their finery to find an off-licence with more. (Photographs by Hilary Little and Jane Shaw-Boden.)

\section{Early life and education in Liverpool}

Sid was born on September $25^{\text {th }}, 1948$, and received his schooling in the city of Liverpool in the North of England. Liverpool at the time was a lively town with the new pop music that began and flourished in that area of the country, and the youth culture that developed in the sixties. As a teenager Sid enjoyed both the music and the social scene, growing up in the city that gave the world the Beatles. A more contemplative pastime that Sid also discovered in those days was fishing, which he continued to pursue throughout his adult life.

\section{DPhil at Oxford University}

Sid went up to Oxford University in 1968 to read biochemistry at Queen's College. Oxford in those days was not the easiest of places for a state-school boy from the north of England, societal differences were considerably greater then than they are now, but Sid soon settled into the University's lively social and academic scene. Stephen Daniels, who was from Manchester, and Sid became close personal friends, sharing the fact that at Oxford they were "outsiders" from the North, albeit from different ends of the East Lancs Road. They first met at the Oxford Underwater Exploration Group (diving club) in 1970. Sid lost interest but it became a major interest in Stephen Daniel's life. Both remained in the Pharmacology Department until 1984 when Sid left for
Switzerland and Stephen Daniels moved to Physical Chemistry.

After completing his first degree in 1972, Sid spent two years working as a research assistant with psychologist and neuroscientist Dr. Edmund T. Rolls in the Experimental Psychology Department at Oxford University. This was something of a change of academic direction for Sid, moving from biochemistry to in vivo studies on the effects of brain stimulation on behaviour, but his time there was prolific, resulting in the publication of several papers in prestigious journals (Rolls et al. 1974a, Rolls et al. 1974b, Mora et al. 1975, Shaw and Rolls 1976). In the same year, at the age of 24, Sid married his first wife, Mary, and they had two sons, Owen and Andrew (Fig. 2).

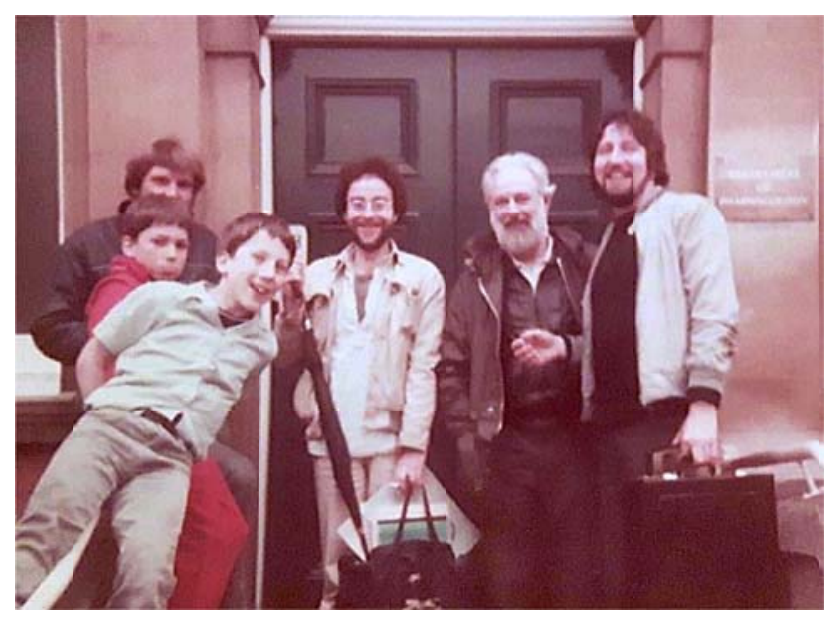

Fig. 2. Sid on his last day at the Diepartment of Pharmacology at Oxford University in 1984. Also pictured are his sons Owen and Andrew. (Photograph by Jane Shaw-Boden.)

\section{Neurobiochemistry and neuropharmacology}

In 1974, Sid moved to the Pharmacology Department in Oxford, to read for a DPhil under the supervision of Dr. Bill Cook, supported financially by a Medical Research Council Studentship. He completed the degree in 1978 (Fig. 1). The topic of his doctoral thesis was "Studies on peptidase enzymes in the central nervous system", which was the start of a long and productive time for Sid working in enzyme biochemistry. His doctoral work resulted in a paper published in Nature in 1978 (Shaw and Cook 1978), as well as in other publications (Shaw and Cook 1979). He demonstrated the selective localisation of arylamidases to specific cells and regions in the mouse $\mathrm{CNS}$, and showed that seven different aminopeptidase enzymes, not previously demonstrated, could be identified in brain. His studies 
also highlighted, and solved, the difficulty of distinguishing between neuronal and vascular locations of the enzymes. These studies, and his later work, helped to lay the foundation for what is now an extensive area of research on the regulation of peptide activity in the brain. Stephen Daniels also made use of Sid's analytical abilities which resulted in a shared publication in the Proceedings of the Undersea Medical Society (Daniels et al. 1981).

The Oxford Pharmacology Department in those days was very active, both scientifically and socially, with a group of DPhil and postdoctoral researchers who (unusually) all came from the same relatively small area in the north of England. These included Stephen Daniels, Richard Vaughan-Jones and Hilary Little, with whom Sid became life-long friends. Conversations were lively and constructive, with key experiments planned, either over coffee in the Department or in local pubs in the evenings, notably the "Royal Oak" on the Woodstock Road and the "Lamb and Flag" on St. Giles. The former was opposite the original Radcliffe Infirmary, where the use of penicillin was first developed in the 1940s and 1950s, and so patrons at the pub would also include young clinicians and hospital workers. Sid was typically the life and soul of his social group.

Following his DPhil (Fig. 1), Sid spent several more years in the Pharmacology Department at Oxford, interrupted by a brief spell at the University of Grenada in Spain as a Visiting European Neuroscience Foundation Fellow. Sid's work in Oxford was supported firstly by the Medical Research Council and then the Wellcome Trust, enabling him to extend his investigations of peptidase enzymes, resulting in several more valuable publications.

In 1982, the Pharmacology Department of Oxford University celebrated its $70^{\text {th }}$ anniversary, and to mark this event Sid and other researchers presented a Comedy Review that included Sid accompanying himself on guitar with a self-penned song entitled "Pharmacology's Growing”. This contribution was particularly appreciated by Department-head, Professor Sir William Paton. Sadly, in those days, video recordings were not a simple matter of using one's mobile phone, so no record of his great performance in this Review exists, except in our memories. But the event emphasizes that Sid's extracurricular activities, particularly in folk music, were as lively and original as his contributions to scientific research.

Another anecdote is from the British Pharmacological Society's $50^{\text {th }}$ Anniversary Meeting in Oxford in 1981 organized by Sir William Paton (19171993) (Hall 1994, Rang 1994, Rang and Lord 1996) where Sid served as a door guard: Sid refused entry to Marthe Vogt (1903-2003) - one of the leading neuroscientists of the $20^{\text {th }}$ century who contributed to the work that won Sir Henry Dale the Nobel Prize in Physiology or Medicine in 1936 (Dale 1936, Dale et al. 1936) - until she found some ID. Oxford's Professor of Pharmacology, Edith Bülbring (1903-1990), another world-renowned scientist (Born 1985, Bolton and Brading 1992), was furious but Marthe Vogt complimented Sid on his diligence.

It was during Sid's later years in Oxford that he met Jane, at the time a chemistry project student of Stephen Daniels undertaking a 12 month research project in the Department. Following his divorce, Sid and Jane became romantically linked. Indeed, they were inseparable as a couple, and remained so for the rest of Sid's life.

\section{Vasoactive peptides and endothelin research}

Sid and Jane left Oxford in 1984 (Fig. 2), travelling to Switzerland to work with Peter Weidmann at the University of Bern. They grew to love the country, its mountains and lakes, and settled there permanently. In the first decade, Sid's scientific focus was directed towards renal pathophysiology and the role of the then newly discovered atrial natriuretic peptides, including urodilatin. The research also branched into clinical work, with seminal studies conducted in human volunteers and in patients (Weidmann et al. 1986a, Weidmann et al. 1986b, Shaw et al. 1987, Ferrier et al. 1988, Saxenhofer et al. 1990).

At the same time, the role of the endothelium in the regulation of vascular tone had become a most active area of research in medicine, and in 1987 nitric oxide was identified as an endothelium-dependent vasodilator a discovery that was awarded the Nobel Prize in Physiology or Medicine in 1998 (Zetterström 2009). Also in 1987, Masashi Yanagisawa, Katsutoshi Goto, Tomoh Masaki and coworkers (Barton et al. 2012a) identified peptide and gene sequences of a group of endotheliumderived vasoconstrictor peptides which they designated endothelins to reflect their endothelial cell origin (Yanagisawa et al. 1988). At the time, measurements of endothelin were limited to circulating levels in plasma, with elevated levels reported in patients suffering from heart failure, atherosclerosis, renal diseases, and diabetes (Rubanyi and Polokoff 1994). The role and regulation of tissue endothelins was entirely unknown. This was largely due to their very low levels of expression. As 
a result, the quantification of local concentrations could not be achieved in small tissue samples.

In 1995, Matthias Barton also moved to the University of Bern, joining the Division of Cardiology as cardiology fellow working on coronary artery disease and atherosclerosis. His research included studying functions of endothelial cell-derived mediators, including endothelin. Since, in many pathological conditions, circulating levels of any vasoactive peptide or hormone can be normal in plasma yet elevated in tissue, Matthias Barton hypothesized at the time that cardiovascular pathologies and therapies might affect production and thus local concentration of endothelin in tissue - even if plasma levels remain largely unchanged. But there was no method to test this hypothesis.

Matthias Barton learned that Sid had just published the measurement of plasma levels of the peptide (Goerre et al. 1995). They met and he explained his "local endothelin system" hypothesis to Sid and that a specific, high-sensitivity assay allowing reliable quantification of endothelins from very small amounts of tissue would be needed to test it. He expected to hear that this would be impossible. But Sid smiled and said: "Let me try something."

Quickly the first tissue samples arrived and Sid and Jane began to work on them immediately, using radioimmunoassay and HPLC techniques. Sid obtained some data from the homogenized tissue but the yield was low and measurements were quite variable. Matthias Barton then came to Sid's lab to introduce a new method he had previously used during his DM thesis work (Mügge et al. 1993a, Mügge et al. 1993b). Extraction of endothelins from pulverized snap-frozen tissue not only resulted in higher yields but also added much to the precision of the assay. Sid smiled and was very happy: he knew that he now had the first assay in his hands that would allow reliable quantification of tissue endothelin levels with very high sensitivity and specificity. Within weeks, he and Jane had extracted and measured numerous samples from studies that were ongoing at the time, establishing the first high-sensitivity and specific ET-1 tissue assay, demonstrating for the first time that cardiovascular and other diseases lead to pronounced activation of the tissue endothelin system. Without doubt, many of the resulting papers published over the next decades were achieved in part because they contained data generated with Sid's ET-1 assay (Barton et al. 1997, Barton et al. 1998, Barton et al. 2000, Vetter et al. 2006).

Sid was soon approached by others wishing to include his new method in their applications for research funding. He quickly sensed that he might become exploited and lose control over the technique he had pioneered. On October 13, 1998, Sid wrote in an e-mail to Matthias Barton: "It was never intended they [the methods] should be included as a whole in any other grant. [...] We spent 3 months developing this molecular biology methodology and there is no way I am handing any details to anyone. The crazy thing is that there must be now several grants submitted which all depend to an important extent on my tissue ET and NO methodology. The problem is we are getting no credit for it and more importantly none of the grants include any request for technical support for this lab (basic costs are one thing but a $20 \%$ technician for example would help considerably. [...] We have an edge which nobody else has and I am not prepared to risk it." Although Sid ended up publishing a large number of articles employing the method he had invented, in the end - as he already felt in 1998 - he did not receive the credit and recognition that he deserved. It is without doubt that the tissue endothelin assay that Sid invented has immensely contributed to endothelin biology, and helped our understanding of intracrine and local effects as well as the regulation of the endothelin system in health, disease, and following therapeutic intervention.

\section{Brain corticosteroids and alcohol research}

In addition to his research in the vasoactive peptide field, for the last 20 years Sid also collaborated with Hilary Little, a psychopharmacologist from the Oxford Department, on a research project on brain corticosteroids. This project arose from a chance conversation when they met at a reunion. The research involved measurements of concentrations of glucocorticoid in different brain areas, and the effects of prolonged alcohol consumption. This had never previously been examined, as the assumption had been made that the brain levels simply followed those in plasma. Sid's broad biochemical experience allowed him to devise reliable methods for the separation, assay and localisation of brain glucocorticoids. These in vivo studies demonstrated prolonged location-specific increases in glucocorticoid levels following withdrawal from chronic alcohol consumption, which may be involved in relapse drinking in abstinent alcoholics (Little et al. 2008, Rose et al. 2010). Hilary Little relates that Sid was a wonderful colleague providing both expertise and support, both when they successfully applied for research grants and published papers, and when, as in all 
research, when things did not go entirely to plan.

\section{Peripheral vascular disease and inflammation immunology}

In March 1998 a Symposium on Endothelin Antagonism was held at the University of Zürich (Gross and Büssemaker 1999) where Matthias Barton had moved the year before. Here Mick Dashwood and Sid first met, and they discussed areas of mutual interest. In the 1970s both were independently involved in projects on the role of monoamines and opioids in brain stimulation-reward mechanisms, Sid at Oxford and Mick Dashwood at the National Institute for Medical Research in north London (Dashwood and Feldberg 1978, Dashwood and Feldberg 1980, Shaw et al. 1984). Also, at a personal level, they shared similar musical tastes of that era, particularly the guitar heroes of the day. As mentioned earlier, Sid was a keen guitarist (Fig. 3).

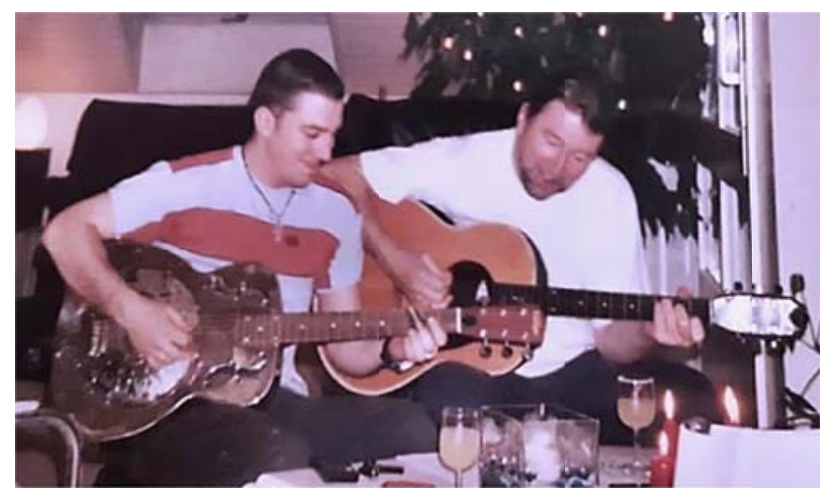

Fig. 3. Sid's son Andrew and Sid playing guitar together at their home in Spiez, Switzerland. (Photograph by Jane Shaw-Boden.)

After getting together a couple of times it became clear that they shared similar research interests and research began to develop in both directions. Soon, Sid's son Andrew brought to Bern samples from clinical studies in London, to be processed in Sid's lab (Dashwood et al. 2009). Sid also visited the Royal Free Hospital, one time bringing with him frozen samples from a diabetes study, neatly prepared in aluminium chocolate cups! A week was spent frantically sectioning and NADPH-diaphorase staining, with results that were equally quickly published (Balsiger et al. 2002).

Mick Dashwood has many memories of times with Sid, meeting up and socialising at various international scientific conferences. Sid missed English beer, after many years of living in Switzerland, so they would often tour various pubs in the Hampstead area during his visits to London, his favourite being the Magdala, sadly now closed. One memorable get-together was when Sid arrived at the Royal Free about two hours later than planned with his son Andrew, both wearing dark suits and black ties. Andrew was a TV cameraman at the time, and was involved in covering the Queen Mother's funeral. Accompanied by the two 'men in black' Mick Dashwood went to enjoy a few beers. All this before meeting Janice Tsui who was treating the three to a 'thank you' French/Thai fusion meal at one of her favourite gastro eateries in Soho. An evening to remember.

Janice Tsui, at the time a vascular surgery fellow at London's Royal Free Hospital working on her MD thesis studying peripheral vascular disease, first met Sid in 2000 when she took a trip to Bern with a collection of muscle biopsy samples to be processed for the various molecular techniques available in Sid's lab. During this two week trip, long hours of concentrated bench work were followed by enjoyable evenings out at local restaurants discussing science, family, music, travel and other passions in life. This was the start of a continued collaboration, looking at the inflammatory pathways in ischaemic skeletal muscle (Patel et al. 2012, Spirig et al. 2012, Navi et al. 2013), as well as a firm friendship. Sid and Jane continued to host young surgeons from London in Bern during this time. Sid was an inspirational mentor not only in science but also in his passion to enjoy every day with all those around him. Sid and Janice Tsui got to know each other's families and made the most of collaborative meetings to meet up.

During that time, Sid and Jane finally tied the knot and got married at the beautiful Schloss Spiez close to Lake Thun in Switzerland in August 2007 - 25 years after having first met each other (Fig. 4).

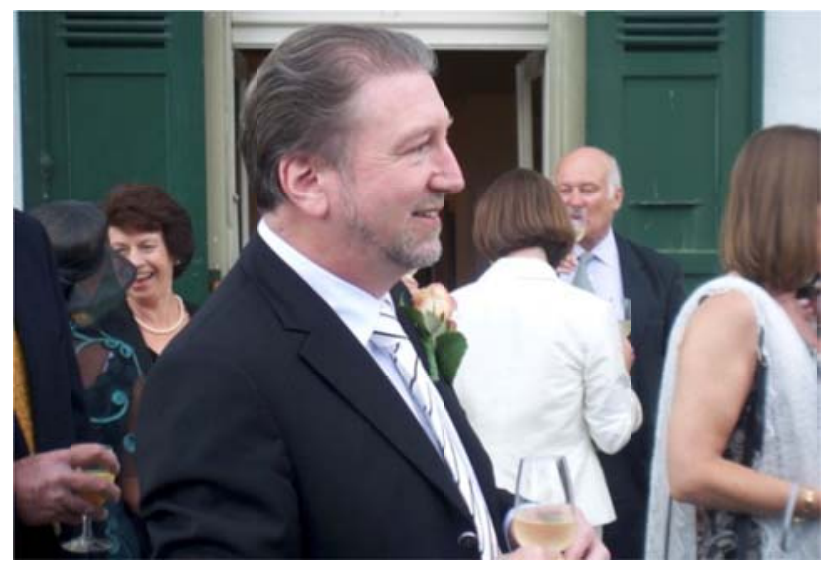

Fig. 4. Sid at his own wedding on 3 August 2007 at Schloss Spiez, Switzerland. (Photograph by Hilary Little.) 

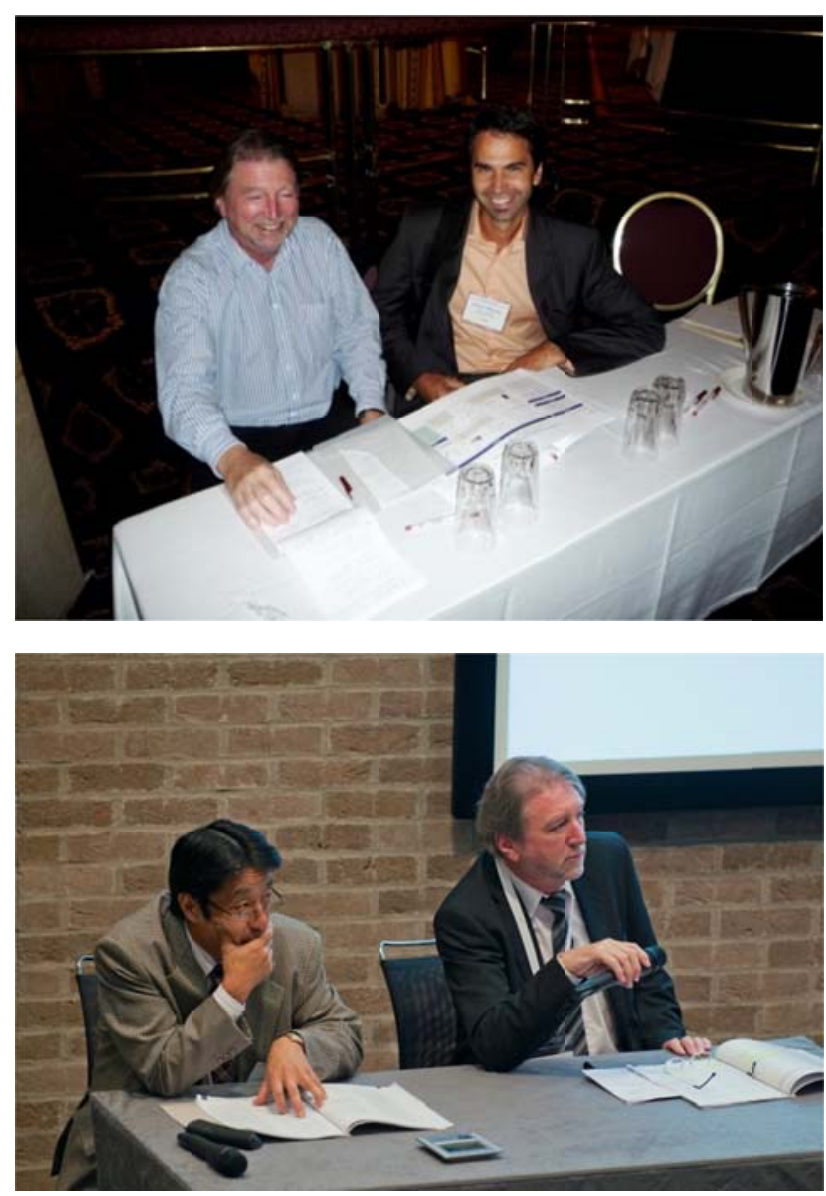

Fig. 5. Sid at the International Conferences on Endothelin, an area of research which he helped advance by pioneering the precise quantification of tissue concentrations of endothelin peptides from very small tissue samples. Above: Sid in 2009 taking notes during the ET-11 meeting held in Montréal, Canada, held in September. Also pictured is Pierre Moreau, at the time at the Université de Montréal, who in the mid-1990s was a post-doctoral fellow at the University of Bern where he also worked with Sid. Below: Sid in 2011, chairing a session at the ET-12 meeting in Cambridge, UK, together with Yasuo Matsumura, Osaka University, Japan. (Photographs by Matthias Barton and Suzette Sandin.)

\section{Remembering Sid}

Sid became an active figure in the endothelin field attending its research conferences, including the Eleventh International Conference on Endothelin in Montréal in 2009; he joined the organizing committee and was a session chair (Fig. 5) at the Twelfth International Conference on Endothelin in Cambridge in the following year (Barton 2012, Barton et al. 2012b). In the same year, Sid co-organized the "International Workshop on the Endothelium in Health and Disease" in London together with Mick Dashwood, Matthias Barton, and David Abraham, the proceedings of the workshop were later published as a book (Abraham et al. 2012).
Over the years, Sid had received prestigious grants, awarded by the Swiss National Science Foundation supporting his research. Sid retired from his position as Head of the Vasoactive Peptide Research Group at the University of Bern in 2013.

Sid supported Janice Tsui in hosting the Royal Free International Cardiovascular Workshops between 2009-2011 and was involved in the European Society of Vascular Surgery Spring Meeting in 2013 in Frankfurt (Navi et al. 2013) and in 2014 in London (Fig. 6). Indeed, Sid invited Richard Vaughan-Jones as a scientific speaker at one of the Royal Free Workshops, thus reinforcing their long friendship after a lapse of several years. Richard Vaughan-Jones recounts that he was grateful for this, as it prompted a recent holiday weekend with Sid and Jane in Dorset, where memories of the Oxford Pharmacology Department were exchanged, friends recalled, and guitar music once again played late into the night. The occasion was a timely book-ending of careers in science.

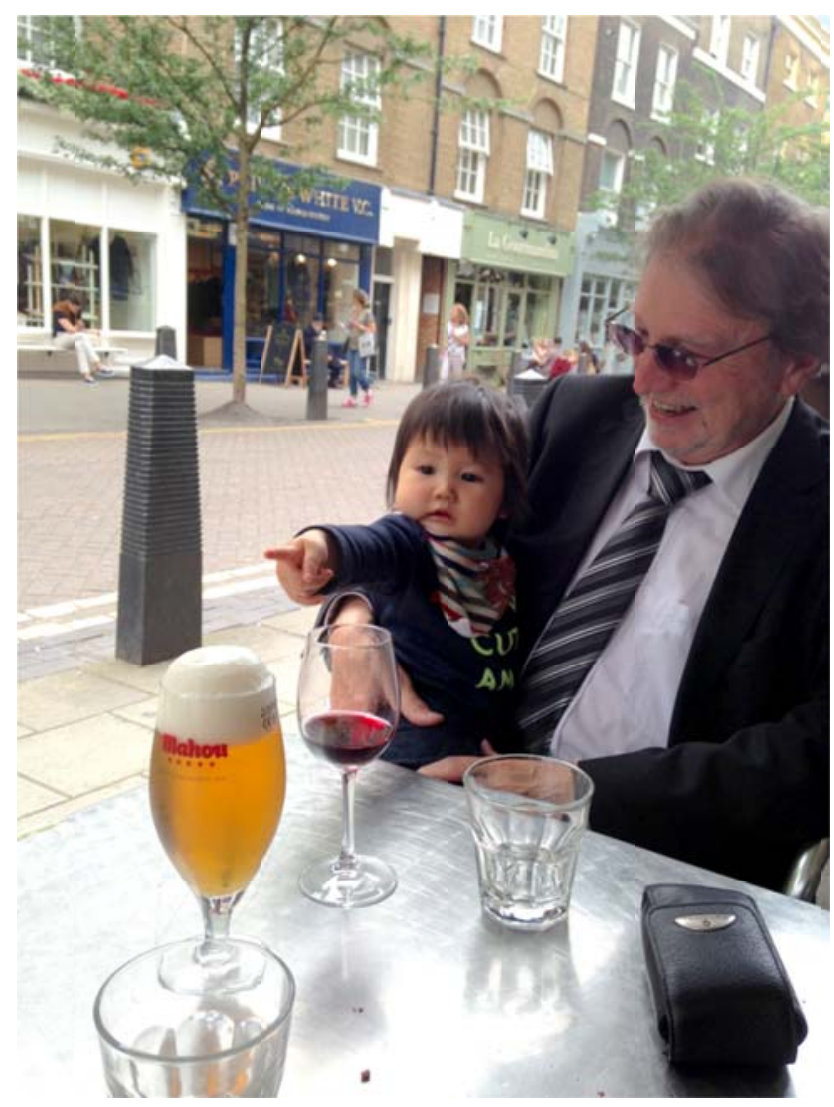

Fig. 6. Sid with Jasper, Janice Tsuii's son, who was 13 months at the time: clearly enjoying lunch at a Spanish restaurant in London after the European Society of Vascular Society Spring Meeting in May 2014. (Photograph by Janice Tsui.) 


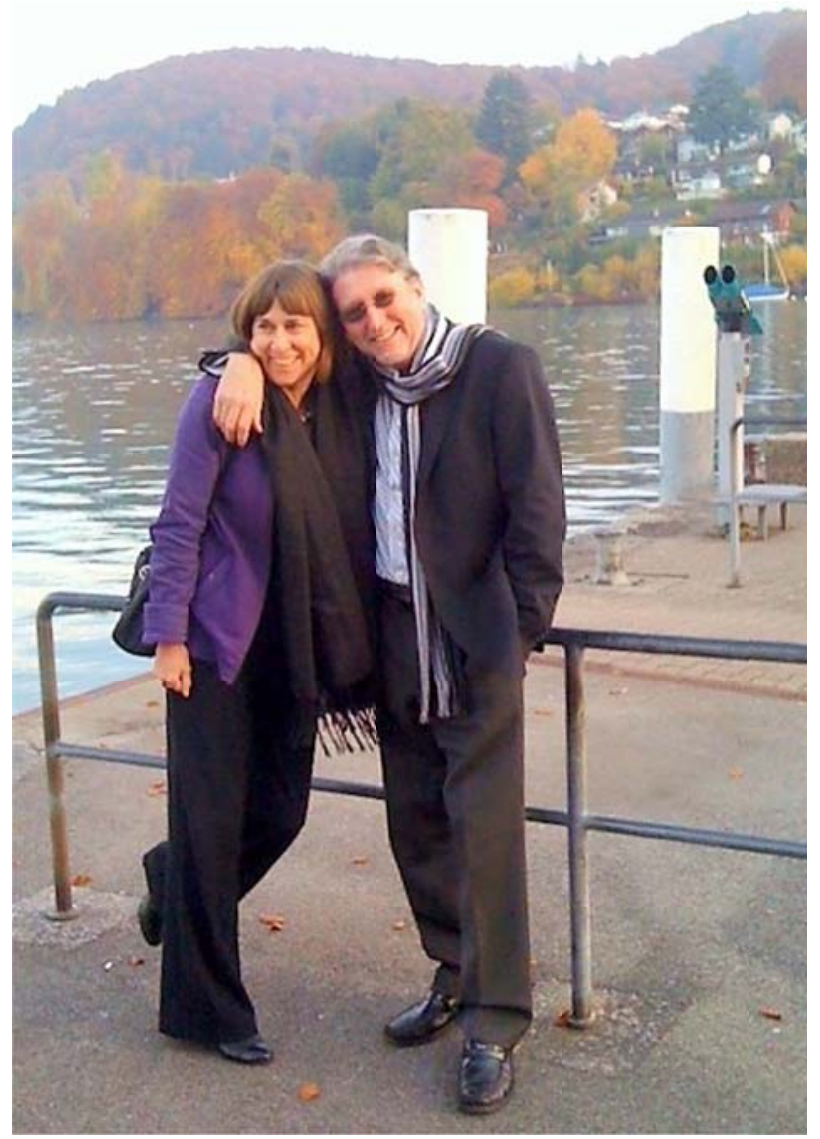

Fig. 7. Jane and Sid by Lake Thun near Spiez in 2011. (Photograph by Hemanshu Patel, Research Fellow in Janice Tsui's group, taken during his visit in Bern.)

Sid loved life, and lived it to the full, both scientifically and socially. In the years following his retirement he and Jane (Fig. 7) had begun travelling all over Europe, and were planning to do so in the years to come. Fate had it that this was going to happen only for a few years, which Jane fondly remembers.

According to Jane, Sid had one true goal in his work: "What Sid wanted was to further science. He was not interested in politics or power play." The former, perhaps the highest goal any scientist should pursue, sometimes got Sid into trouble with others more interested in the latter. It meant so much to Sid that he and his colleagues had been able to bring new medical treatment approaches all the way from the first ideas and the laboratory studies to the clinic where they are making a difference to peoples' lives. Sid was one of the most intellectually curious scientists we have ever met. He was a humble, honest, and warm-hearted man who so much loved what he was doing. He will remain an example for all of us, we remember him both as a scientist and as a warm, outgoing and loyal friend (Fig. 8). Our feelings are with his wife and his children. We, his friends, mourn that his life was cut short far too early.

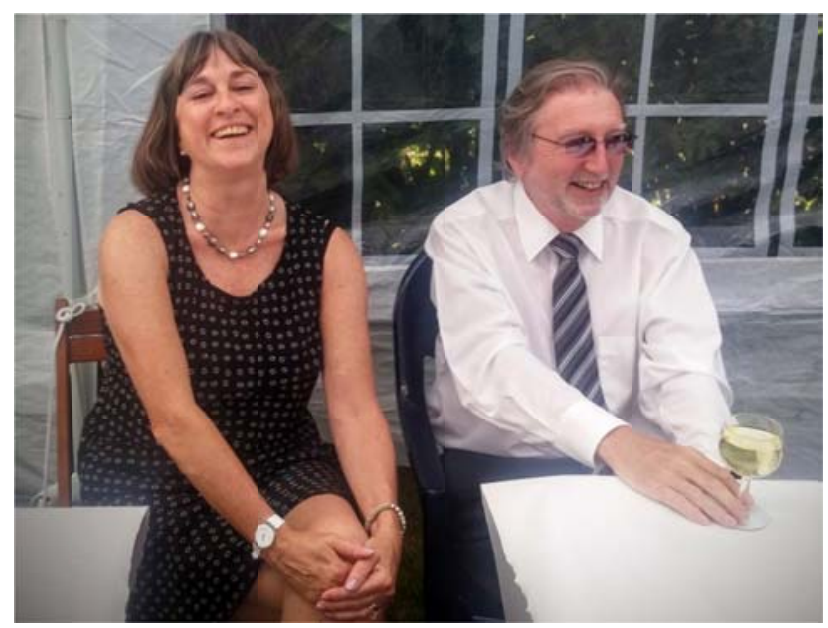

Fig. 8. Jane and Sid at a friend's wedding in 2016. (Photograph by Jane Shaw-Boden.)

\section{Acknowledgements}

We thank Jane Shaw-Boden, Owen Shaw, and Andrew Shaw, for sharing personal memories and photographs and for critically reading a draft of the manuscript.

\section{References}

ABRAHAM D, HANDLER C, DASHWOOD MR, COGHLAN G (eds): Translational Vascular Medicine. Pathogenesis, Diagnosis, and Treatment. Springer, London, 2012, pp 1-268.

BALSIGER B, RICKENBACHER A, BODEN PJ, BIECKER E, TSUI J, DASHWOOD M, REICHEN J, SHAW SG: Endothelin A-receptor blockade in experimental diabetes improves glucose balance and gastrointestinal function. Clin Sci (Lond) 103 (Suppl 48): 430S-433S, 2002.

BARTON M (ed.): Endothelin XII - Proceedings of the Twelfth International Conference on Endothelin, Clare College, University of Cambridge, United Kingdom, September 11-14, 2011. Life Sci 91: 449-750, 2012.

BARTON M, SHAW S, D'USCIO LV, MOREAU P, LUSCHER TF: Angiotensin II increases vascular and renal endothelin-1 and functional endothelin converting enzyme activity in vivo: role of $\mathrm{ET}_{\mathrm{A}}$ receptors for endothelin regulation. Biochem Biophys Res Commun 238: 861-865, 1997. 
BARTON M, HAUDENSCHILD CC, D'USCIO LV, SHAW S, MÜNTER K, LUSCHER TF: Endothelin ET $_{\mathrm{A}}$ receptor blockade restores NO-mediated endothelial function and inhibits atherosclerosis in apolipoprotein E-deficient mice. Proc Natl Acad Sci U S A 95: 14367-14372, 1998.

BARTON M, CARMONA R, MORAWIETZ H, D'USCIO LV, GOETTSCH W, HILLEN H, HAUDENSCHILD CC, KRIEGER JE, MÜNTER K, LATTMANN T, LUSCHER TF, SHAW S: Obesity is associated with tissuespecific activation of renal angiotensin-converting enzyme in vivo: evidence for a regulatory role of endothelin. Hypertension 35: 329-336, 2000.

BARTON M, EMOTO N, MIYAUCHI T: The First Tomoh Masaki Award (2011). Life Sci 91: 466-469, 2012a.

BARTON M, YANAGISAWA M, VANHOUTTE PM, MASAKI T: Endothelin XII. Life Sci 91: 449-451, 2012b.

BOLTON TB, BRADING AF: Edith Bülbring: 27 December 1903 - 5 July 1990. Biogr Mem Fellows R Soc 38: 69-95, 1992.

BORN GV: Edith Bülbring. Experientia 41: 839-840, 1985.

DALE HH: Nobel Lecture: Some recent extensions of the chemical transmission of the effects of nerve impulses. December 12, 1936. Nobelprize.org. Nobel Media AB 2014. http://www.nobelprize.org/nobel_prizes/ medicine/ laureates/1936/dale-lecture.html.

DALE HH, FELDBERG W, VOGT M: Release of acetylcholine at voluntary motor nerve endings. $J$ Physiol 86: 353-380, 1936.

DANIELS S, GREEN AR, KOBLIN DD, LISTER HJ, LITTLE HJ, PATON WDM, BOWSER-RILEY F, SHAW SG, SMITH EB: Pharmacological investigation of the high pressure neurological syndrome: brain mono-amine concentrations. Proceedings of the VII Symposium on Underwater Physiology. Undersea Medical Society, Bethesda, 1981, pp 329-335.

DASHWOOD MR, FELDBERG W: A pressor response to naloxone. Evidence for release of endogenous opioid peptides. J Physiol 281: 30P-31P, 1978.

DASHWOOD MR, FELDBERG W: Release of opioid peptides in anaesthetized cats? Br J Pharmacol 68: 697-703, 1980.

DASHWOOD MR, SAVAGE K, TSUI JC, DOOLEY A, SHAW SG, FERNANDEZ ALFONSO MS, BODIN L, SOUZA DS: Retaining perivascular tissue of human saphenous vein grafts protects against surgical and distension-induced damage and preserves endothelial nitric oxide synthase and nitric oxide synthase activity. J Thorac Cardiovasc Surg 138: 334-340, 2009.

FERRIER C, WEIDMANN P, HOLLMANN R, DIETLER R, SHAW S: Impaired response of atrial natriuretic factor to high salt intake in persons prone to hypertension. N Engl J Med 319: 1223-1224, 1988.

GOERRE S, STAEHLI C, SHAW S, LUSCHER TF: Effect of cigarette smoking and nicotine on plasma endothelin-1 levels. J Cardiovasc Pharmacol 26 (Suppl 3): S236-S238, 1995.

GROSS P, BÜSSEMAKER E: Second Symposium on Endothelin Antagonism, Zürich, Switzerland, March 5-7th, 1998. Nephrol Dial Transplant 14: 790-792, 1999.

HALL AR: Sir William Paton (1917-93). Br J Hist Sci 27: 465-466, 1994.

LITTLE HJ, CROFT AP, O'CALLAGHAN MJ, BROOKS SP, WANG G, SHAW SG: Selective increases in regional brain glucocorticoid: a novel effect of chronic alcohol. Neuroscience 156: 1017-1027, 2008.

MORA F, SANGUINETTI AM, ROLLS ET, SHAW SG: Differential effects on self-stimulation and motor behaviour produced by microintracranial injections of a dopamine-receptor blocking agent. Neurosci Lett 1: 179-184, 1975.

MÜGGE A, RIEDEL M, BARTON M, KUHN M, LICHTLEN PR: Endothelium independent relaxation of human coronary arteries by 17 beta-oestradiol in vitro. Cardiovasc Res 27: 1939-1942, 1993a.

MÜGGE A, RIEDEL M, BARTON M, KUHN M, LICHTLEN PR: Estrogen dilates human coronary arteries in vitro by an increase in cyclic GMP and cyclic AMP smooth muscle content. Eur Heart J 14: 16, 1993 b.

NAVI A, PATEL H, SHAW S, BAKER D, TSUI J: Therapeutic role of toll-like receptor modification in cardiovascular dysfunction. Vascul Pharmacol 58: 231-239, 2013.

OSLER W: Doctor and Nurse. Remarks to the First Class of Graduates from the Training School for Nurses of the Johns Hopkins Hospital. Graduation speech. John Murphy \& Company, Baltimore, 1891, pp 1-11. 
PATEL H, YONG C, ABRAHAM D, BAKER D, SHAW S, TSUI J: Activation of the toll-like receptor (TLR) adapter protein MyD88 is detrimental to skeletal muscle in critical limb ischemia (CLI). Arterioscl Thromb Vasc Biol 32: A146, 2012.

RANG H: William Paton (1917-1993). Trends Pharmacol Sci 15: 15, 1994.

RANG HP, LORD P: Sir William Drumond Macdonald Paton, C.B.E.: 5 May 1917 - 17 October 1993. Biogr Mem Fellows R Soc 42: 291-314, 1996.

ROLLS ET, KELLY PH, SHAW SG: Noradrenaline, dopamine, and brain-stimulation reward. Pharmacol Biochem Behav 2: 735-740, 1974a.

ROLLS ET, ROLLS BJ, KELLY PH, SHAW SG, WOOD RJ, DALE R: The relative attenuation of self-stimulation, eating and drinking produced by dopamine-receptor blockade. Psychopharmacologia 38: 219-230, 1974b.

ROSE AK, SHAW SG, PRENDERGAST MA, LITTLE HJ: The importance of glucocorticoids in alcohol dependence and neurotoxicity. Alcohol Clin Exp Res 34: 2011-2018, 2010.

RUBANYI GM, POLOKOFF MA: Endothelins: molecular biology, biochemistry, pharmacology, physiology, and pathophysiology. Pharmacol Rev 46: 325-415, 1994.

SAXENHOFER H, RASELLI A, WEIDMANN P, FORSSMANN WG, BUB A, FERRARI P, SHAW SG: Urodilatin, a natriuretic factor from kidneys, can modify renal and cardiovascular function in men. Am J Physiol 259: F832-F838, 1990.

SHAW SG, COOK WF: Localisation and characterisation of aminopeptidases in the CNS and the hydrolysis of enkephalin. Nature 274: 816-817, 1978.

SHAW SG, COOK WF: The histochemical localisation of aminopeptidases in the central nervous system and an analysis of factors contributing to the final staining pattern. Histochemistry 63: 145-154, 1979.

SHAW SG, ROLLS ET: Is the release of noradrenaline necessary for self-stimulation of the brain? Pharmacol Biochem Behav 4: 375-379, 1976.

SHAW SG, VIVES F, MORA F: Opioid peptides and self-stimulation of the medial prefrontal cortex in the rat. Psychopharmacology (Berl) 83: 288-292, 1984.

SHAW SG, WEIDMANN P, HODLER J, ZIMMERMANN A, PATERNOSTRO A: Atrial natriuretic peptide protects against acute ischemic renal failure in the rat. J Clin Invest 80: 1232-1237, 1987.

SPIRIG R, TSUI J, SHAW S: The emerging role of TLR and innate immunity in cardiovascular disease. Cardiol Res Pract 2012: 181394, 2012.

VETTER D, SHAW SG, BRANDES RP, MÜNTER K, VETTER W, BARTON M: Beneficial cardiovascular effects of endothelin $\mathrm{ET}_{\mathrm{A}}$ receptor blockade in established long-term heart failure after myocardial infarction. Exp Biol Med (Maywood) 231: 857-860, 2006.

WEIDMANN P, HASLER L, GNADINGER MP, LANG RE, UEHLINGER DE, SHAW S, RASCHER W, REUBI FC: Blood levels and renal effects of atrial natriuretic peptide in normal man. $J$ Clin Invest 77: 734-742, 1986a.

WEIDMANN P, HELLMUELLER B, UEHLINGER DE, LANG RE, GNAEDINGER MP, HASLER L, SHAW S, BACHMANN C: Plasma levels and cardiovascular, endocrine, and excretory effects of atrial natriuretic peptide during different sodium intakes in man. J Clin Endocrinol Metab 62: 1027-1036, 1986 b.

YANAGISAWA M, KURIHARA H, KIMURA S, TOMOBE Y, KOBAYASHI M, MITSUI Y, YAZAKI Y, GOTO K, MASAKI T: A novel potent vasoconstrictor peptide produced by vascular endothelial cells. Nature 332: 411-415, 1988.

ZETTERSTRÖM R: The 1998 Nobel Prize - discovery of the role of nitric oxide as a signalling molecule. Acta Paediatr 98: 593-599, 2009. 